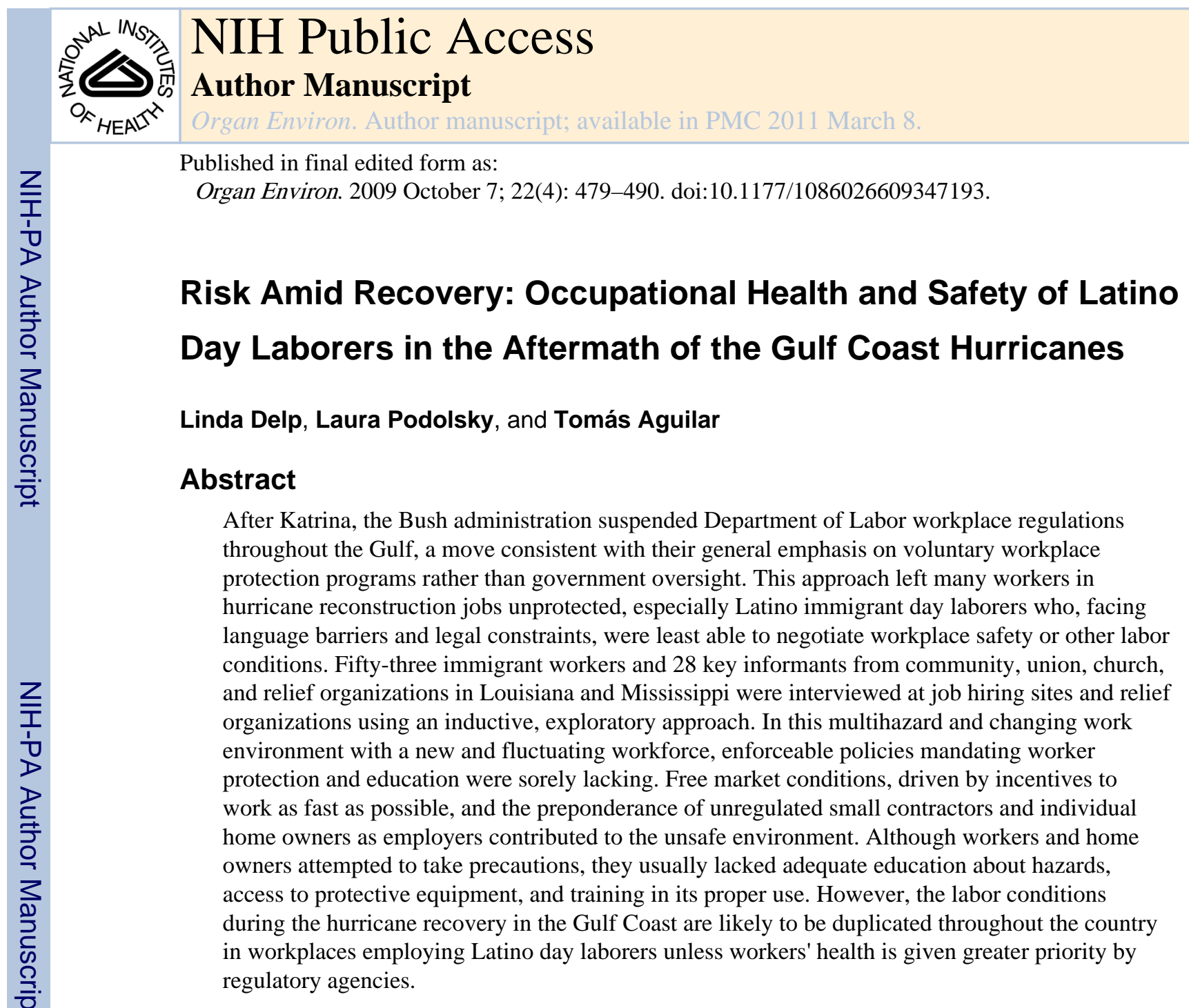

Keywords

day laborers; Gulf Coast Hurricane; worker health and safety

\title{
Introduction
}

By September 2005, labor was scarce in the Gulf Coast, and many former residents were too devastated by their losses from the hurricane and flooding to return to their former homes. The lack of government regulation of the labor market in the wake of the disaster meant that the recovery would occur in a truly free market. Thus, the need for demolition and construction employment was met by a day labor workforce that was largely made up of Latino immigrants, a group particularly vulnerable to exploitation (Fussell, 2006; Government Accountability Office [GAO], 2002; Fletcher, Pham, Stover \& Vinck,

\footnotetext{
The content is solely the authors' and does not necessarily represent the views of the NIEHS or NIH. Results from this research were reported in an earlier report in 2006, by University of California, Los Angeles, Labor Occupational Safety and Health Program (UCLA-LOSH) and National Day Laborer Organizing Network (Aguilar \& Podolsky, 2006). Aguilar also presented preliminary results at a March 2006 meeting in Birmingham, Alabama, convened by NIEHS to evaluate the effectiveness of federal response efforts to meet worker health and safety training needs in the Gulf Coast. See Aguilar and Podolsky (2006) for the report, and National Clearinghouse for Worker Safety and Health Training (2006) for proceedings and a report from the NIEHS meeting.

Declaration of Conflicting Interests The authors declared no conflicts of interest with respect to the authorship and/or publication of this.
} 
2007).The organization of this labor force through both overt and latent social processes is a critical but often overlooked component of disaster response.

Day laborers face a host of work-related hazards even in the best of conditions. A national study found that one in five day laborers is injured on the job (Valenzuela, Theodore, Melèndez, \& Gonzalez, 2006). Stories from the Gulf Coast cleanup effort suggest that working conditions there held more than the usual dangers: mold, toxic materials, respiratory problems, skin rashes, and a lack of protective equipment were but a few.

In response to these reports of potentially dangerous working conditions, the University of California, Los Angeles, Labor Occupational Safety and Health Program (UCLA-LOSH) and the National Day Laborer Organizing Network joined forces to investigate occupational health and safety issues among Latino day laborers in the region. Tomás Aguilar, a day labor organizer and field researcher, traveled to the Gulf Coast to learn about working conditions, governmental regulatory responses, and possibilities for collaborating with other groups to improve conditions. He visited the region for 12 days in December 2005, returning three more times in January and February for a total of 30 days. This research supplemented a larger needs assessment funded by the National Institute for Environmental Health Sciences (NIEHS) to aid in developing worker health and safety education programs during the rebuilding effort.

The study used an inductive, exploratory approach consisting of open-ended interviews with workers and key informants and participant observation at job hiring sites and relief organizations. The researcher interviewed 53 immigrant workers and 28 key informants from community, union, church, and relief organizations in Louisiana and Mississippi. He interviewed workers where they congregated, primarily at street corner hiring sites. Interviews were voluntary and no names or other identifying information was gathered. All workers were Spanish-speaking day laborers, that is, they were hired on a daily or project basis by contractors or home owners without immediate prospects for long-term employment. Although Aguilar did not ask workers about their legal status, given findings from other studies, it is likely that the majority lacked legal documents (Aguilar \& Podolsky, 2006; Fletcher, Pham, Stover, \& Vinck, 2006; National Clearinghouse for Worker Safety and Health Training, 2006; Valenzuela et al., 2006).

In a variety of ways, the work-related health and safety needs of this population were not being met; they lacked safety equipment, training, and basic housing and health care services. Local community organizations and relief agencies lacked the capacity and resources to provide services to Spanish-speaking workers, and the federal government responded in ways that further exacerbated the problems. We discuss the distinctive challenges of improving day laborers' working conditions and access to health carechallenges tied both to the particular nature of day labor and to the postdisaster context. We highlight systemic reasons underlying the government's failure to prioritize workers' health and describe the response of worker advocates.

\section{Workers' Health in Jeopardy}

Like other workers and returning residents, day laborers confronted a variety of hazards when demolishing, cleaning, and gutting buildings. Mold was most frequently mentioned, but a variety of safety hazards were also common, such as working on roofs with no fall protection and exposure to unknown hazardous substances. Two informants, for example, were hired to work on a crew collecting debris from the streets and loading it onto a large truck. They were provided no protective equipment even though the loads were classified as toxic, containing chemicals, asbestos, or other toxic material. In the immediate post-Katrina environment there was no system for protecting workers from these hazards. 
Occupational health and safety professionals and regulators use three levels of intervention to deal with hazards: (a) at the environmental level to eliminate hazards by changing equipment, machinery, and other aspects of the work environment; (b) at the administrative level to control hazards, such as changes in workplace policies, training, and work organization (e.g., shift length, speed of work); and (c) at the individual level to provide workers with personal protective equipment. The Occupational Safety and Health Administration (OSHA), recognizing the limitations of personal protection, requires employers to adopt a "hierarchy of controls" in which the use of personal protective equipment is considered the final level of protection to ensure against the failure of the earlier levels. In disasters, where such equipment is necessary, OSHA mandates the type of equipment to be used and worker training to ensure its effectiveness.

Traditionally, this three-level framework is applied to a workplace with clear hazards, a stable workforce, and formal employer-employee relationships, in some cases governed by labor- management agreements. OSHA may inspect and cite those employers who fail to comply with the relevant worker protection standards. None of these conditions were met in reconstruction efforts in the Gulf Coast: OSHA stated it would not inspect work sites and cite employers, so neither the standard employment relationship nor the official government role was applied in this setting.

The selection and effective use of personal protective equipment is critical to worker safety - respirators must be appropriate to the type of air contaminant and fitted to the individual, gloves and other clothing must protect against specific hazards, workers must be provided a clean storage area, and clothing, masks, and filters must be replaced when damaged or clogged. Furthermore, workers must be educated to effectively use the equipment.

Workers interviewed for this research confirmed the paucity of training and protective equipment documented elsewhere (Fletcher et al., 2006). They further elaborated on the condition of the equipment provided, casting doubt on its effectiveness and indicating that conditions may have been even worse than documented in quantitative surveys.

In this multihazard and changing work environment with a new and fluctuating workforce, enforceable policies mandating worker protection and education were critical but sorely lacking. Free market conditions, driven by incentives to work as fast as possible and the preponderance of unregulated small contractors and individual home owners as employers contributed to the unsafe environment. In this setting, workers were left to their own devices. Some attempted to take precautions, using whatever protective equipment they could obtain - usually without any training on its proper use. The few who had been trained said much of the information was incomprehensible owing to language differences. Multiple workers interviewed were reusing protective masks and suits from previous jobs. Miguel, from Guatemala, had used the same mask for 5 weeks to protect against exposure to mold while cleaning and gutting houses. When issued the mask at his first job in New Orleans, Miguel understood little of the employer's instructions, in English, for using the mask to protect against mold. "I'm not worried about my health," he said, "I've been fine so far. I'm fortunate to have this face mask from a previous job five weeks ago. I wound up keeping the mask."

While Miguel may have obtained a false sense of security from a 5-week-old mask, Manlio was one of the few workers interviewed who refused work that he perceived as unacceptably dangerous.

Many of these contractors want you to go up on a roof with nothing to hold you up but a rope tied to a tree or nailed to the roof with a normal-sized nail. Well, have 
you ever been up on a roof being held up by only a nail on a rope? It's scary. It's not for me. Leave it for the young daredevils. I'm too old for that.

Other workers saw hazards as part of the job and questioned whether they warranted much concern. One interviewee, nicknamed El Conejo, thought the protective suits were excessive.

We come to work. Period. If you get sick, well, that's just your luck. You could get sick by not working as well. Let's not go overboard with these funny-looking suits. For the most part, it's basic work, plain and simple.

For El Conejo and others, the driving imperative was to earn money, and the more difficult it was to earn money the less workers could afford to prioritize health and safety. Carlos, originally from Mexico, came to New Orleans with a Dallas-based contractor who promised good wages. However, he eventually lost his job.

Of course I would love safer working conditions. Of course I would like to be able to shake this cough. But until I get settled with a good boss, one who treats us like human beings and not mules, I have no choice but to take any job-whether they offer protective gear or not. So no, I don't demand protective gear as a condition of employment, not while I'm sleeping on the streets.

Like Carlos, many workers returned to dismal temporary housing conditions at the end of the work day-some lived in tents pitched in muddy fields, others in crowded, mold-covered hotel rooms rented from employers. Some workers simply slept in their cars. Many workers had no place to shower or wash clothes after hours of exposure to mold and toxic chemicals.

"The place was musty and the ceiling moldy," said Tomás, who accompanied workers to their sleeping quarters.

Over 100 people slept in bunk beds stacked three beds high. There was coughing everywhere. Gerardo had been nursing a chest cold which wouldn't go away. I took him to a local clinic where he was given some medicine for the cough and told to get some rest.

Socioeconomic constraints, language, and legal status created a climate of fear in which workers were afraid to ask questions or assert their rights. Workers who spoke up faced losing wages, jobs, and housing or being reported to immigration authorities or police. Manuel and coworker Gabriel, both from Guatemala, preferred "the misery we know. If we lost our jobs, where would we go? At least we're not sleeping in the rain." Ramón could speak from experience. Owed more than 2 weeks pay, he complained to the contractor. The supervisor then convened a meeting with the contractor and all the workers, asserting that the workers had been paid. "The boss believed him [the supervisor] and told us to leave," said Ramón.

When we tried to explain in our broken English to the boss how the supervisor had lied, the boss called the police on us. We ran away before the police arrived, but now we are sleeping in cars with no money in our pockets.

In some ways, this situation differed little from the day labor experience elsewhere. The "informal economy" of day laborers is characterized by job hazards, job insecurity, a lack of legal protections, and almost no employer accountability (Buchanan, 2004; GAO, 2002; Valenzuela et al., 2006). Yet the combination of factors in the Gulf Coast-the changing and sometimes unpredictable hazards of disaster sites, the social and legal status of day laborers, and the potential for exploitation by unscrupulous or uneducated employers-increased the risk of exposure to workplace hazards beyond those faced in nondisaster sites and greater than those faced by native-born, English-speaking workers. Similarly, a lack of access to 
health care is not new to day laborers but was uniquely shaped by the postdisaster environment of the Gulf Coast.

\section{Access to Health Care}

Day laborers injured on the job often do not seek medical care. In a national study of day laborers, more than one half of the workers who reported work-related injuries did not receive the medical care they needed for the injury. Only $6 \%$ reported that their workers compensation insurance covered their medical expenses (Valenzuela et al., 2006). Language barriers, lack of affordable care, concern over missing work, and lack of transportation all impede their access to care. Immigration status also plays a role. Fearing incarceration or deportation, many undocumented workers are reluctant to enter clinics and hospitals (Buchanan, 2004). A recent study in California demonstrated that undocumented Latinos, particularly from Mexico, used fewer health care services and had worse experiences with care than their U.S.-born counterparts, even after controlling for sociodemographics, insurance, and need (Ortega et al., 2007). In the Gulf Coast during the rebuilding phase, common health problems ranged from a cold or the flu to recurring headaches and eye infections. Despite similar health complaints, workers with legal documents were four times more likely than undocumented workers to seek medical treatment (Fletcher et al., 2006).

Access to care for work-related injuries is a right afforded to workers regardless of legal status. In Gulfport, Mississippi, workers' access to information about their rights was stymied by language barriers. Aguilar accompanied two workers to a job center, where they completed Spanish-language job applications of several pages in formal, legalistic language. When one of the workers did not understand some of the questions, the clerk told him that the questions were routine, that they should "just initial and sign the papers." On reading it more closely, Aguilar discovered that it contained information about what to do if injured on the job.

Disaster sites expose workers to multiple hazards and require an infrastructure capable of providing health care services for injuries under the workers' compensation system. Also important is a mechanism to track long-term or unknown health effects. Mold, one of the primary hazards reported by workers, may not produce immediate symptoms, and other hazards specific to the post-hurricane cleanup may have unknown or similarly delayed effects. The experiences at ground zero at the World Trade Center site are both foreboding and instructive. In New York, pressure from an established labor movement and worker advocacy groups led to funding for medical screening and data collection through New York's occupational health infrastructure. Health professionals involved in medical screening at the World Trade Center urged state and federal leaders to "prepare for the complex physical and mental health issues...certain to arise in future disasters" including the "rapid establishment of both diagnostic and treatment programs" as well as follow-up for exposed workers (Herbert et al., 2006, p. 1858). Four years after the September 11, 2001, attacks, neither these preparations nor an occupational health infrastructure were in place when the hurricanes hit the Gulf Coast, leaving an uncertain prognosis for the many exposed workers, particularly those who did not seek medical care or who did so anonymously. These workers, disproportionately undocumented Latino workers, will have no record of their exposures or their health problems. This will in turn make it difficult for public health officials to document the long-term effects of exposure and for health care providers to determine the source of workers' health problems and the appropriate treatment.

The nature of the migrant workforce in Gulf Coast rebuilding efforts ensures that while some will settle others will move on and be lost to follow-up through official channels (Fussell, 2006). Given these realities, the situation of day laborers poses a challenge to 
traditional public health approaches to worker health and safety, approaches that presume a degree of stability in the workforce and employment relationships as well as a level of accountability that does not exist for day laborers, particularly those working in disaster settings.

\section{Production versus Protection: Response of Federal Agencies}

The situation of day laborers in the Gulf Coast was in some ways similar to employer abuse seen elsewhere. What distinguished the hardship faced by these workers, however, was the government's de facto endorsement of it. A crisis on the scale of Hurricanes Katrina and Rita calls for special government measures, but those taken by the Bush administration were inadequate, ill advised, and tinged with racism that resulted in disparate impacts on residents and workers alike (Pastor et al., 2006). Consequently, federal policies negatively affected the ability of government agencies to fulfill their mission to protect workers' health.

On September 8, 2005, President Bush suspended the Davis-Bacon Act, which requires federal contractors to pay prevailing wages. He justified his decision by saying that DavisBacon increases construction costs, and "suspension [of the Act] will result in greater assistance to these devastated communities and will permit the employment of thousands of additional individuals"(Edsall, 2005, p. D03). Supporters of this move claimed that prevailing wage regulations that bar contractors from paying low wages "effectively discriminate against contractor employment of non-union and lower-skilled workers" and "can even raise total construction costs by up to 38 percent" (Whittaker, 2005, p. CRS-17). The way to cut costs, they implied, was to cut wages. Labor leaders decried this reasoning. AFL-CIO president John Sweeney strenuously objected, saying,

Employers are all too eager to exploit workers. This is no time to make that easier... Taking advantage of a national tragedy to get rid of a protection for workers that corporate backers of the White House have long wanted to remove is nothing less than profiteering. (Whittaker, 2005, p. CRS-18)

The New York Times concurred: "By any standard of human decency, condemning many already poor and now bereft people to sub-par wages - thus perpetuating their poverty - is unacceptable" (New York Times, 2005). From a worker safety perspective, low wages create the need to work more hours regardless of the risk, and they limit workers' options to refuse hazardous jobs. Under pressure from the labor movement and worker advocacy groups, the administration reinstated requirements to pay prevailing wages on October 26, 2005.

In this environment of suspended labor regulations, OSHA followed suit, announcing that it would not enforce workplace health and safety standards and would focus instead on providing consultation and technical assistance to employers. This policy remained in effect in the most seriously damaged areas for more than a year, leaving OSHA without teeth to enforce its own standards (GAO, 2007; National Clearinghouse for Worker Safety and Health Training, 2006). ${ }^{1}$

OSHA's announcement was not the only indication that enforcement of worker safety standards was not a priority. The failure of the Federal Emergency Management Agency (FEMA) to provide timely assistance in responding to worker safety needs was another indication. The National Response Plan (NRP), created after the World Trade Center attack

\footnotetext{
1 OSHA notes that it did not "suspend" enforcement, rather "the agency delayed planned inspection activities as appropriate to the unique circumstances." They resumed full enforcement in stages, beginning January 25, 2006, in Florida, Alabama, and some parts of Mississippi and Louisiana, then on June 28 throughout the rest of Mississippi, and, finally on September 15, throughout the rest of Louisiana (see U.S.GAO-07-93, Appendix IV: Comments from the Department of Labor and GAO's response, 2007).
} 
to enhance government capacity to manage domestic incidents, triggers OSHA protective action in response to disasters, but only after it receives a mission assignment from FEMA. In this case, FEMA did not issue that assignment until September 21, 2005, more than 3 weeks after the hurricane struck.

As required under the NRP, OSHA had developed a Health and Safety Plan to protect workers involved in hurricane recovery operations. That plan, however, applied only to workers employed by federal agencies or by federal contractors-and those agencies responsible for implementing the plan were either unaware of its existence or ignored its requirements. They did not incorporate requirements of the plan into the federal contracts they issued, nor did they have a mechanism to enforce worker protection requirements for federal contract workers or for workers hired by their subcontractors (National Clearinghouse for Worker Safety and Health Training, 2006).

Although actions beyond OSHA's control hampered its effectiveness in the region, this inefficacy was also because of its own delays. Eight months prior to the Gulf Coast hurricanes, OSHA had been tasked under the NRP with developing a plan to ensure that workers were provided protective equipment during a disaster and with developing a process to collect and monitor data on work-related injuries and illnesses. Despite the health consequences of exposure to harmful conditions at the World Trade Center, OSHA was ill prepared when Hurricanes Katrina and Rita struck. With no guidance beforehand from OSHA, data collection by federal agencies was, by all accounts, lacking. The GAO reports that, with few exceptions, agencies could not provide accurate figures on the number of their own employees in the region, failed to track the number of contract employees for which they were responsible, and kept incomplete, unreliable, or inconsistent records of workrelated injuries and illnesses, making it difficult to compile data and monitor trends over time (GAO, 2007).

Inaction by FEMA and in turn OSHA stymied efforts of the NIEHS Worker Education and Training Program, established in 1987, to create model health and safety training for hazardous waste workers and emergency responders (Slatin, 2009). Owing to a series of bureaucratic delays, it was not until the end of October that OSHA finally approved NIEHS training materials and courses. These delays translated into weeks and even months of cleanup work with little regard for worker protection. Longtime educators from one NIEHS training program confirmed the dangers when they finally arrived:

We were called about large truck "tip-overs" and vehicle wrecks at two sites where hundreds of trucks were dumping tons of hurricane debris. On November 15th it came to a head... no work would be conducted and no debris dumped until everyone went through a safety briefing at the sites. We set up one 20 minute briefing station in front of a large dump truck that had tipped over the day before... When work stops during a disaster recovery, something very dangerous indeed is happening. For contractors paid by the load... every minute that these people weren't using their machines or loading or unloading debris meant money lost out of their own pockets. (National Clearinghouse for Worker Safety and Health Training, 2006, p. 9)

Even for workers hired under federal contract and for whom the government had the most leverage, the training was extremely limited and was required only after serious accidents. A sharply worded report by the NIEHS 6 months after the hurricanes struck assessed the situation as a major "systems failure."

Rather than providing the comprehensive safety and health training that is necessary and required, most of the resources have been devoted to short-term, justin-time, hazard awareness training... Worker safety and health and related training 
are simply not a priority and are, it appears, only an annoyance that hinders the "production operation" mentality that was also characteristic of the WTC response and cleanup. (National Clearinghouse for Worker Safety and Health Training, 2006, p. 11)

These critiques were leveled at employers who had the most resources and those with federal contracts. Federal agencies that issued those contracts did not require contractors to comply with OSHA's Health and Safety Plan. Nor did OSHA, which had suspended compliance operations, enforce worker safety standards. ${ }^{2}$ Thus, much of the subcontracted work that occurred throughout the cleanup was done without any OSHA oversight.

Many have debated the effectiveness of OSHA's alternative strategy to provide consultation and technical assistance rather than enforcement. OSHA contends that it was able to reach more workers and employers than would have been possible if inspectors had been required to follow the legal procedures involved in issuing citations. In this setting, inspectors' only enforcement authority was to stop work that created an imminent hazard, that is, possible death. All other activities depended primarily on their powers of persuasion.

A bilingual Cal/OSHA staff member who assisted in the region for 2 weeks in November reported on the devastation, the need for education and protection, and the effort required to persuade workers and employers to use protective equipment and take precautions.

Many workers could not read or read very poorly. When asked, many did not know the hazards associated with mold, asbestos, spiders and structural instability...The [OSHA] fact sheets provided critical facts; however, [even in Spanish] they have too much text for hurricane recovery workers with minimal reading skills. We quickly put together a [visual] fact sheet to explain how to properly use a respirator.

Many roofers were unskilled, ill equipped and working at dangerous heights to get the job done quickly...Workers inside a confined space-a vault full of mud and debris, dark, wet and restrictive - heard the alarms going off on the oxygen and gas meters and thought something was wrong with the instrument. Our interventions usually involved a short "tailgate" type safety meeting... several questions, reading a few things and informing workers of the risk and safeguards. ${ }^{3}$

This same staff member informed supervisors that "we would most likely check back" to ensure they were following through with safeguards. However, state OSHA staff was temporary and federal OSHA staff levels were limited, with only 84 staff members deployed on October 1 and November 1, well under $1 \%$ of the total number of federal employees in the region $(\mathrm{GAO}, 2007)$.

In this dangerous environment, a public announcement from the official work safety agency that it would not enforce its worker protection regulations left workers to the mercy of contractors and subcontractors. These employers were paid by how fast they worked and thus were hesitant to pay workers for time spent in safety training. Without the impetus of OSHA enforcement, employers were not signing up for training, even training provided free of charge by NIEHS programs. Jurisdictional constraints that limited training to federal employees and those under federal contracts further circumscribed the reach of NIEHS and other federal programs. State and local workers not hired under federal contract and workers

\footnotetext{
${ }^{2}$ One applicable regulation was the Hazardous Waste Operations and Emergency Response Standard (29 CFR 1910.1200), which requires employers to train "any employees who are exposed or potentially exposed to hazardous substances" during cleanup of hazardous wastes or emergency response. See

http://www.osha.gov/pls/oshaweb/owadisp.show_document?p_table=STANDARDS\&p_id=9765

${ }_{3}^{3}$ PowerPoint presentation, Michael Alvarez, "Katrina Recovery, New Orleans-November 2005; Experiences and Lessons

Learned," at Cal/OSHA Advisory Committee meeting, Los Angeles, California, May 5, 2006.
} 
hired by small contractors or by residents were ineligible for free training available through NIEHS-funded programs, including those programs with the capacity to provide training in Spanish and Vietnamese. The NIEHS report 6 months after the hurricanes asserted that OSHA's failure to enforce training regulations provided no incentives for federal contractors to train workers and noted that local lower tier contractors lacked both knowledge of training requirements and funding to deliver effective safety and health training to their workforce. The report states, "It is assumed that [contractors supply workers with health and safety training] and that such applies to all lower-tier subcontractors, which is an invalid assumption during a disaster response action." Training, required by law under normal circumstances, represented "an added expense for subcontractors-one not reimbursed by the government" (National Clearinghouse for Worker Safety and Health Training, 2006, p. $15)$.

Although many workers were too often inadequately protected or trained, Latino day laborers had access to even fewer resources. Our investigation found that many small contractors and private home owners themselves lacked knowledge of hazards and protections. Some did not have money to pay for safety gear while others saw hiring day laborers as a way of circumventing such requirements and expectations. One small contractor said he preferred to hire day laborers precisely because he did not have to provide them with safety equipment. He said it "was understood" that the workers, as "independent contractors," would provide their own "tools and anything else, including safety gear like goggles and gloves." Others, knowing that OSHA was not enforcing regulations, decided "we're not going to take the time for training" (National Clearinghouse for Worker Safety and Health Training, 2006, p. 16).

In summary, federal response in this disaster setting was marked more by delays and confusion than by aggressive action to protect workers' health. While OSHA deployed many dedicated staff to the region, their efforts were stymied by a failure at the highest level of government to prioritize workers' health. Federal contracts did not require the recipients of federal funds to incorporate OSHA's Health and Safety Plan; OSHA publicly declared that it would not enforce regulations to protect workers; and interagency constraints initially stalled NIEHS efforts to provide free worker training and ultimately disallowed training for nonfederal workers most in need of protection. Thus, government decisions to temporarily suspend certain labor regulations, ostensibly meant to facilitate the recovery process, supported the ongoing exploitation of day laborers and other workers (Browne-Dianis, Lai, Hincapie, \& Soni, 2006).

\section{Convergence: Worker Safety and Government Inaction}

Community groups struggled to meet the overwhelming needs of workers and to fill the gaps created by government inaction, albeit with limited resources. Nonprofit organizations initially lacked educational material and staff to work with the day laborers. To determine how accessible safety gear was to those left to their own devices, Aguilar attempted to obtain safety equipment for workers. He found that the gear was either unavailable or available only for certain groups of residents or workers. Security personnel and volunteers from the Red Cross/ FEMA site in New Orleans initially denied him entrance, stating that their services were only for local residents. When he finally gained access, staff informed him that they had no equipment to distribute and referred him to a relief organization across the street. That organization, however, had no protective equipment, nor was it equipped with bilingual staff or materials, although staff expressed interest in resources that would enable them to meet the needs of Spanish-speaking workers. 
Many of the problems that surfaced after Katrina are not new. Rather, the hurricanes made visible to the world the social inequities that existed for both displaced residents and Latino day laborers, many of whom also migrated to escape deteriorating economic and social conditions in their home towns albeit under less sudden and less catastrophic conditions. The situation day laborers faced in the Gulf Coast are a microcosm of issues that affect workers elsewhere, although in this case magnified by disaster and government inaction.

In the absence of government resources or control, grassroots organizations advocated for workers by educating them about their rights, obtaining and providing safety equipment while supplies lasted, providing or facilitating access to health care services, and documenting the situation from worker and residents' perspectives. A Congress of Day Laborers has been established to address issues specific to day laborers. Activities include organizing on street corners and facilitating relationships with residents, business owners, and city officials (Reckdahl, 2007). The Congress recently affiliated with the National Day Laborers Organizing Network, creating broader links to other worker advocates and the organized labor movement.

The day laborers' network, unions, and other worker advocacy groups ultimately must join forces to confront the systemic failure of government agencies to protect workers, a failure most obvious in the Gulf Coast but also evident elsewhere. Government response to worker health and safety needs in the Gulf Coast followed a trajectory that had begun well before Katrina. Under the Bush administration, OSHA consistently deemphasized enforcement of worker safety regulations in favor of cooperation, with a focus on strengthening partnerships with industry and voluntary protection programs.

One year before the hurricanes hit, then OSHA director John Henshaw highlighted his priorities in a speech to the U.S. Department of Labor National Safety Congress, ironically, in New Orleans. The speech devoted less than a page to enforcement while the remaining five pages described OSHA's emphasis on cooperative programs and campaigns to encourage workers to use safe work practices, all indicators of OSHA's nonassertive approach to educate workers about their rights and to enforce employer compliance with worker protection regulations. ${ }^{4}$ This approach essentially left many workers in hurricane reconstruction jobs on their own, with an added impact on Latino day laborers who, facing language barriers and legal constraints, were least able to negotiate safety or other labor conditions. Tragically, the results of government failure to protect workers were already evident among workers at another disaster site, the World Trade Center.

OSHA's response to the dangers of recovery and reconstruction work in the Gulf Coast was less a change in course than the continuation of its existing approach, one that left workers unprotected in what has been called the "Wild West" of a free market cleanup, where financial incentives spurred work at dangerous speeds with no counterbalancing mandates and few resources to protect workers' health. This confluence of the forces of natural and technological disasters in the Gulf Coast—destruction from hurricanes and flooding shaped by sociopolitical factors - exposed the particular vulnerabilities of Latino day laborers in both normal and exceptional circumstances.

\section{Acknowledgments}

Funding The authors disclosed receipt of the following financial support for the research and/or authorship of this article:

\footnotetext{
${ }^{4}$ Henshaw's speech is available at http://www.osha.gov/pls/oshaweb/owadisp.show_document?p_table=SPEECHES\&p_id=780 (Retrieved May 2008).
} 
Funding was provided by Grant No. U45ES006173 from the National Institute of Environmental Health Sciences to UCLA-LOSH.

\section{Biographies}

Linda Delp is director of UCLA-LOSH, the Labor Occupational Safety \& Health Program, and of the Western Region Universities Consortium HazMat Training Program. She has a PhD from the UCLA School of Public Health where her research focused on the job conditions of home care workers. She serves on the Advisory Board of WORKSAFE, a statewide policy organization, and on Advisory Committees of Cal/ OSHA, the Southern California Coalition for Occupational Safety and Health, and the Occupational Safety and Health Section of the American Public Health Association.

Laura Podolsky, MPH, worked at the UCLA Labor Occupational Health and Safety Program (LOSH) from 2004 to 2007, working with LOSH's Young Worker Health \& Safety Project, evaluation efforts, and materials development. She is currently in law school at UCLA, focusing on health care law.

Tomás Aguilar is codirector of Colectivo Flatlander supporting the immigrant rights movement. He worked at Workers Defense Project supporting Gulf Coast organizations working with immigrant day laborers. He previously worked at Alternatives for Community \& Environment and United for a Fair Economy, both in Boston. He grew up in Laredo, Texas, and currently lives in Austin.

\section{References}

Aguilar, T.; Podolsky, L. Risk amid recovery: Occupational health and safety of Latino immigrant workers in the aftermath of the Gulf Coast hurricanes. University of California, Los Angeles, Labor Occupational Safety and Health Program and National Day Laborer Organizing Network; Los Angeles: 2006. Retrieved August 31, 2009, from http://www.losh.ucla.edu/research-policy/katrina.html

Browne-Dianis, J.; Lai, J.; Hincapie, V.; Soni, S. And injustice for all: Workers' lives in the reconstruction of New Orleans. Advancement Project, National Immigration Law Center, and New Orleans Workers' Center for Racial Justice; New Orleans, LA: 2006. Retrieved August 31, 2009, from http://www.advancementproject.org/reports/workersreport.pdf

Buchanan S. Day labor and occupational health: Time to take a closer look. New Solutions: Journal of Environmental and Occupational Health 2004;14:253-260.

Edsall TB. Bush suspends pay act in areas hit by storm. The Washington Post September 9;2005 :D03.

Fletcher, L.; Pham, P.; Stover, E.; Vinck, P. Rebuilding after Katrina: A population-based study of labor and human rights in New Orleans. Jun. 2006 (Study released by the University of California, Berkeley, and Tulane University). Retrieved August 31, 2009, from http://www.law.berkeley.edu/news/2006/ Katrina\%20Report-June7.pdf

Fletcher L, Pham P, Stover E, Vinck P. Latino workers and human rights in the aftermath of hurricane Katrina. Berkeley Journal of Employment and Labor Law 2007;28:107-162.

Fussell, E. Latino immigrants in Post-Katrina New Orleans. regional seminar on Labor Rights; New Orleans, LA. Oct 19-22. 2006 Retrieved August 31, 2009, from http://www.tulane.edu/ sociol/documents/latino_migrants.pdf

Government Accountability Office. Worker protection: Labor's efforts to enforce protection for day laborers could benefit from better data and guidance. Washington, DC: Author; Sep. 2002 GAO-02-925Retrieved August 31, 2009, from http://www.gao.gov/new.items/d02925.pdf

Government Accountability Office. Better planning would improve OSHA's efforts to protect workers' safety and health in disasters. Washington, DC: Author; Mar. 2007 GAO-07-193Retrieved August 31, 2009, from http://www.gao.gov/new.items/d07193.pdf 
Herbert R, Moline J, Skloot G, Metzger K, Baron S, Luft B, et al. The World Trade Center disaster and the health of workers: Five-year assessment of a unique medical screening program. Environmental Health Perspectives 2006;114:1853-1858. [PubMed: 17185275]

National Clearinghouse for Worker Safety and Health Training. Learning from disasters: Hurricane Katrina response safety and health training: Report of a national technical workshop. Author; Washington, DC: May. 2006 Retrieved August 31, 2009, from http://tools.niehs.nih.gov/wetp/1/06SpringMeeting/docs/WETP06_SpringMtgReport_Final.pdf

New York Times. A shameful proclamation. Sep 10. 2005 (Editorial). Retrieved August 31, 2009, from http://www.nytimes.com/2005/09/10/opinion/10sat2.html?scp=6\&sq=editorial+september+10+2 005\&st=nyt

Ortega N, Fang H, Perez V, Rizzo J, Carter-Pokras O, Wallace S, et al. Health care access, use of services, and experiences among undocumented Mexicans and other Latinos. Archives of Internal Medicine 2007;167:2354-2360. [PubMed: 18039995]

Pastor, M.; Bullard, R.; Boyce, J.; Fothergill, A.; Morello-Frosch, R.; Wright, B. In the wake of the storm: Environment, disaster, and race after Katrina. Russell SAGE Foundation; New York: 2006.

Reckdahl, K. Day laborers organize a spot in the job market. Apr 16. 2007 Retrieved August 31, 2009, from http://blog.nola.com/topnews/2007/04/day_laborers_organize_a_spot_i.html

Slatin, C. Environmental unions: Labor and the superfund. Baywood; New York: 2009.

Valenzuela, A.; Theodore, N.; Melèndez, E.; Gonzalez, AL. On the corner: Day labor in the United States. The National Day Labor Study. University of California, Los Angeles, Center for the Study of Urban Poverty; Los Angeles: Jan. 2006

Whittaker, WG. The Davis-Bacon Act: Suspension. Congressional Research Service; Washington, DC: Sep 26. 2005 Library of Congress Order Code RL33100Retrieved August 31, 2009, from http://opencrs.cdt.org/document/RL33100/ 